\title{
DAMAGE RATIOS FOR LOW-RISE NON-DOMESTIC BRICK BUILDINGS IN THE MAGNITUDE 7.1 WAIRARAPA, NEW ZEALAND, EARTHQUAKE OF 24 JUNE 1942
}

\author{
D.J. Dowrick ${ }^{1,2}$ and D.A. Rhoades ${ }^{1,3}$
}

\begin{abstract}
SUMMARY
An analysis of damage costs to low-rise non-domestic brick buildings in the MM8 intensity zone of the $M_{w} 7.1$ Wairarapa earthquake of 24 June 1942 has evaluated the vulnerability of such buildings in New Zealand for the first time. The buildings studied were mostly of unreinforced brick of average workmanship and material quality, i.e. the second most vulnerable class of New Zealand buildings. Approximate vulnerabilities were also determined for partly reinforced and partly retrofitted buildings, and for one and two-storey buildings. The costs of damage were derived from insurance claims and local government records. The indicators of vulnerability that were determined were the statistical distributions and mean values of damage ratios, and the percentage of buildings damaged. Comparisons have also been made with results from studies of other earthquakes.
\end{abstract}

\subsection{INTRODUCTION}

In 1942, a series of damaging earthquakes occurred in the Wairarapa province of New Zealand. The locations and general effects of these earthquakes have recently been studied by Downes et al. [1]. The largest event in the sequence ( $24^{\text {th }}$ June) was of magnitude $M_{s} 7.2\left(M_{w} 7.1\right)$ [2] with a centroid depth of approximately $12 \mathrm{~km}$ [3], while the second to largest event ( $1^{\text {st }}$ August) was of magnitude $\mathrm{M}_{\mathrm{s}} 7.0$ $\left(M_{w}\right.$ 7.0) [2] with a centroid depth of $40 \mathrm{~km}$ [3]. The focal mechanisms of these two main shocks were strike-slip and normal respectively.

Although the largest event was quite shallow, its fault rupture did not reach the surface, the depth to the top of the rupture probably being 4 or 5 kilometres. This, coupled with the fact that this earthquake comprised two sub-events [3], helps explain why the maximum intensity observed was barely Modified Mercalli IX (MM9), despite the overall event magnitude being $M_{w} 7.1$. As seen from the isoseismal map, the strongest isoseismal was intensity MM8 and the earthquake was felt as far afield as Auckland and Dunedin (Figure 1).

The area inside the MM8 isoseismal, (i.e. the MM8 zone), was predominantly a farming area (population approximately 24,000 ), and so the total losses were quite low in national economic terms. However, in the six largest towns (Figure 2 ), there were numerous brick buildings, most of which suffered moderate to serious damage. About a quarter of these buildings had earthquake insurance, and the economic impact of the earthquake losses was worsened considerably

\footnotetext{
${ }^{1}$ Institute of Geological \& Nuclear Sciences, Lower Hutt

${ }^{2}$ Fellow

${ }^{3}$ Member
}

by the prevailing stringent restrictions on building and the business recession caused by World War II. The costs of the repairs to the damaged buildings come from data compiled by the borough council engineers, lead by CR Mabson of Masterton, in efforts to secure permits from the national government to use strenuously controlled materials and labour resources in the repairs. How these repair costs were affected by wartime conditions is not known, e.g. were economies sought?

The damage costs for a variety of classes of property have already been studied by the present authors for the 1931 Hawke's Bay, 1968 Inangahua and 1987 Edgecumbe earthquakes [4-9].

In the present case we have a representative and statistically reasonably robust set of data for studying the degree of damage to a class of buildings in terms of damage ratio, $D_{r}$, defined as

$D_{r}=\frac{\text { Cost of Damage to a Building }}{\text { Replacement Value of that Building }}$

As in the previous studies, the damage ratios are studied here as a function of intensity of ground shaking, restricted this time to one intensity, MM8, as defined for New Zealand [10] in Appendix 1.

The present study offers us our first opportunity to evaluate the vulnerability of brick buildings at any level of hazard providing nearly an upper bound estimate of the vulnerability 
of any class of New Zealand building, albeit for only one earthquake and only one intensity. Extra costs would be incurred today as strengthening of URM would be required.

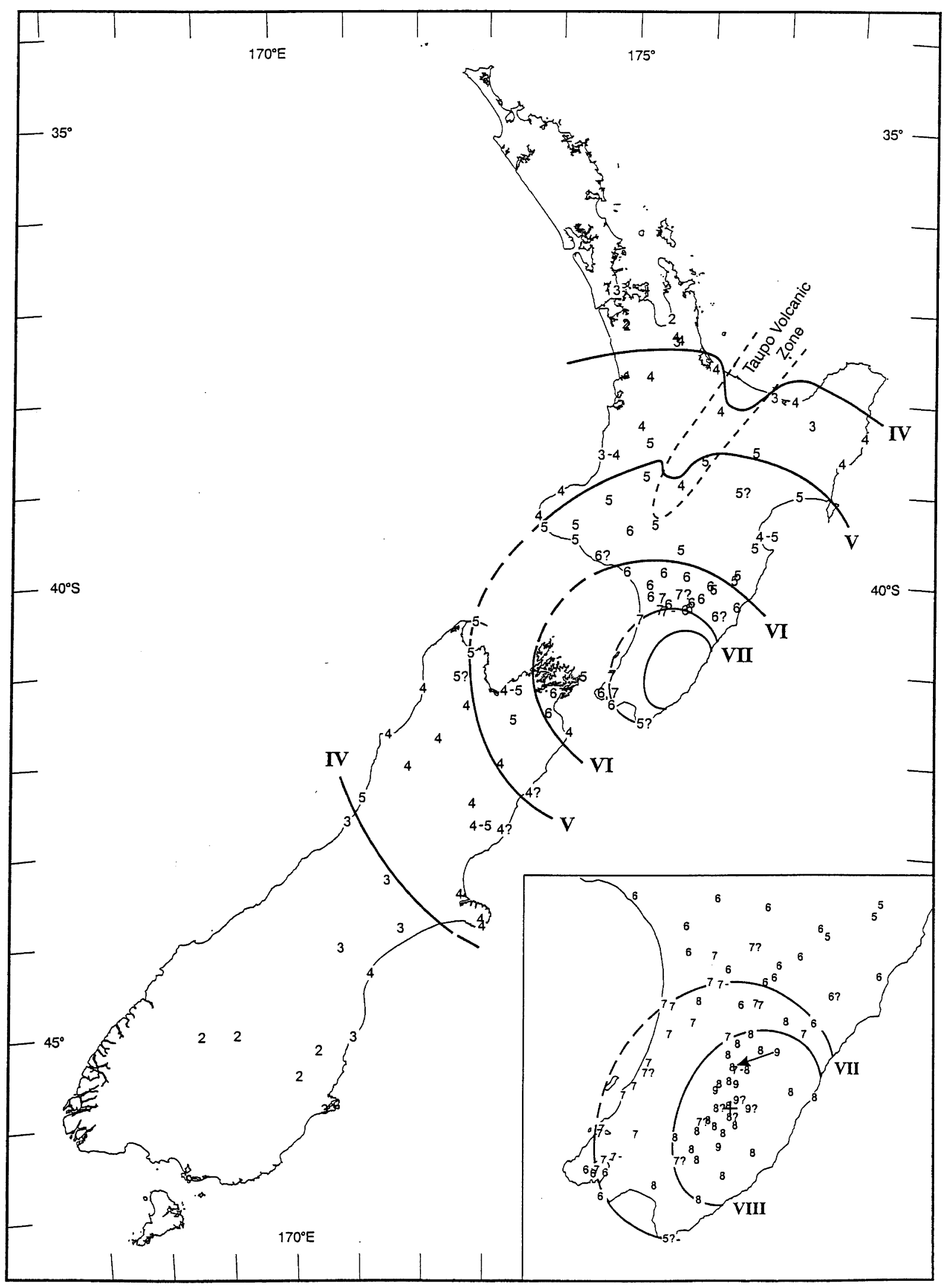

Figure 1: $\quad$ Map showing Modified Mercalli intensity isoseismals of the $M_{W} 7.1$ Wairarapa earthquake of $24^{\text {th }}$ June 1942 (adapted from Downes et al., [1]). 


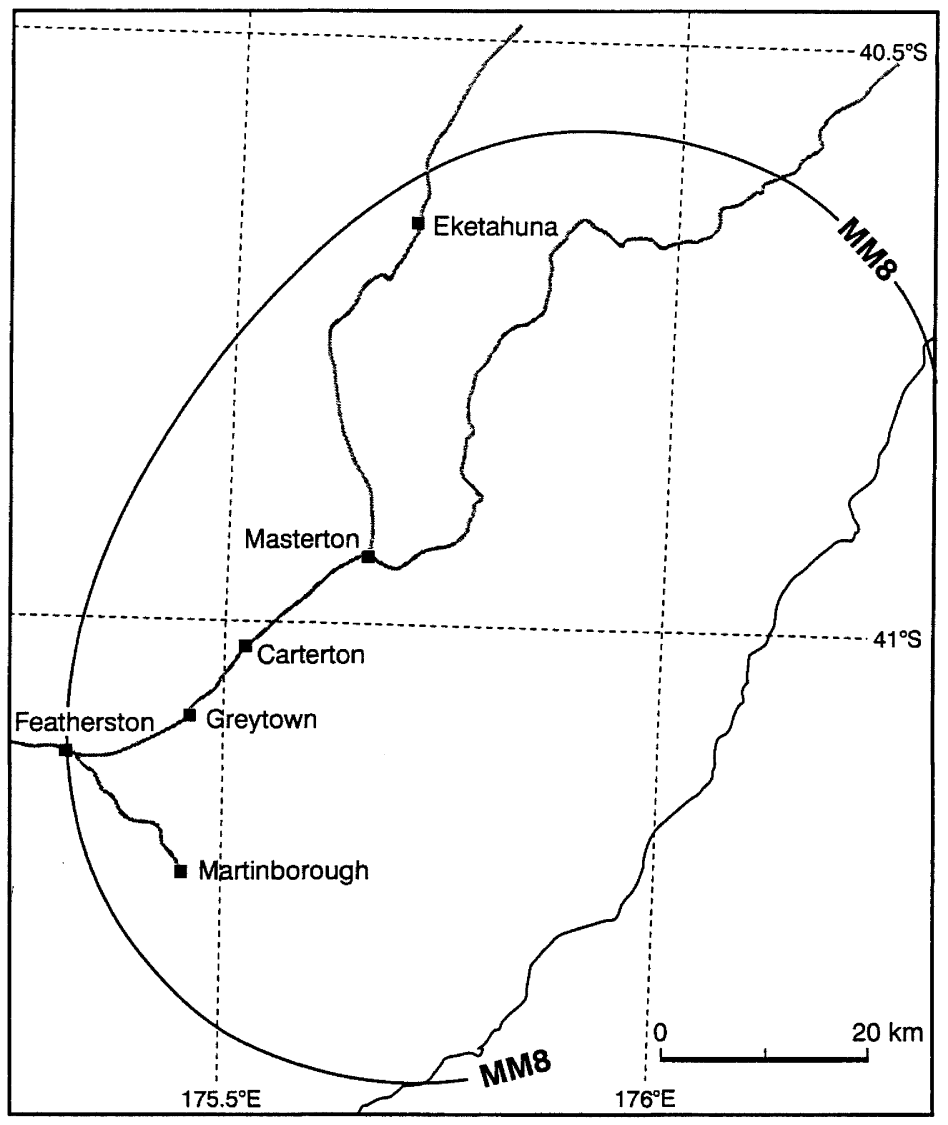

Figure 2: $\quad$ Map showing the innermost isoseismal, MM8, state highways and key place names for the $24^{\text {th }}$ June 1942 Wairarapa earthquake.

\subsection{DESCRIPTION OF THE BUILDINGS STUDIED}

All of the buildings studied were of non-domestic use, i.e. commercial, light industrial or institutional, and were built predominantly of brickwork. Most buildings were of pure unreinforced brick (Figure 3 ) while a few featured reinforced concrete beams at floor and/or roof level, and a few had been partially retrofitted with attached reinforced concrete beams and/or columns after the $M_{w} 7.4$ Pahiatua earthquake of 1934[11]. In two buildings the strength of the brickwork was supplemented by structural steel members. The geographical distribution of the buildings studied was as follows: Carterton (17), Eketahuna (17), Featherston (3), Greytown (3), Masterton (79) and Martinborough (10).

The buildings were all low-rise, i.e. 79 were one-storey, 48 were two-storey and two were three-storey. A few of the single storey buildings had high walls, and some of these featured two-storey construction over a small part of the ground plan area, such as the Opera House in Masterton (Figure 4).

Horizontal diaphragms, i.e. suspended floors and roofs, were of timber construction.

The buildings have been divided into three classes of vulnerability:

1. Pure brick (With horizontal diaphragms of timber);

2. Hybrid (Brick with some concrete or steel members as part of the original construction);
3. Retrofitted (Originally pure brick, with some concrete or steel members added after the 1934 Pahiatua earthquake). The eight such buildings in our dataset were all considered at the time [12] to be only partly retrofitted, and recommendations to complete the strengthening were made. These attempts at retrofitting are almost the earliest in New Zealand known to us, there being some cases in Hawke's Bay after the 1931 Hawke's Bay and 1932 Wairoa earthquakes.

The pure brick buildings, Item 1 above, were of ordinary workmanship and materials, without any extreme weaknesses. Thus they conform to the class of construction described in the MM intensity scale as "Buildings Type II" (See Appendix 1), and are thus the second most vulnerable class of building in New Zealand.

"Buildings Type I", i.e. the most vulnerable class, where recognised, were excluded from our database. Three of the four Type I buildings were: St Matthews Church in Masterton and the two-storey Post Offices (with brick clock towers) in Masterton and Carterton; two of these buildings had to be pulled down after the earthquake. Included in the dataset were seven buildings that were considered not worth repairing (i.e. $D_{r}=1$ ), comprising one two-storey building each in Masterton and Carterton, and two buildings of one storey and three of two storeys in Eketahuna.

The basic statistics of the buildings studied are summarized in Table 1. 


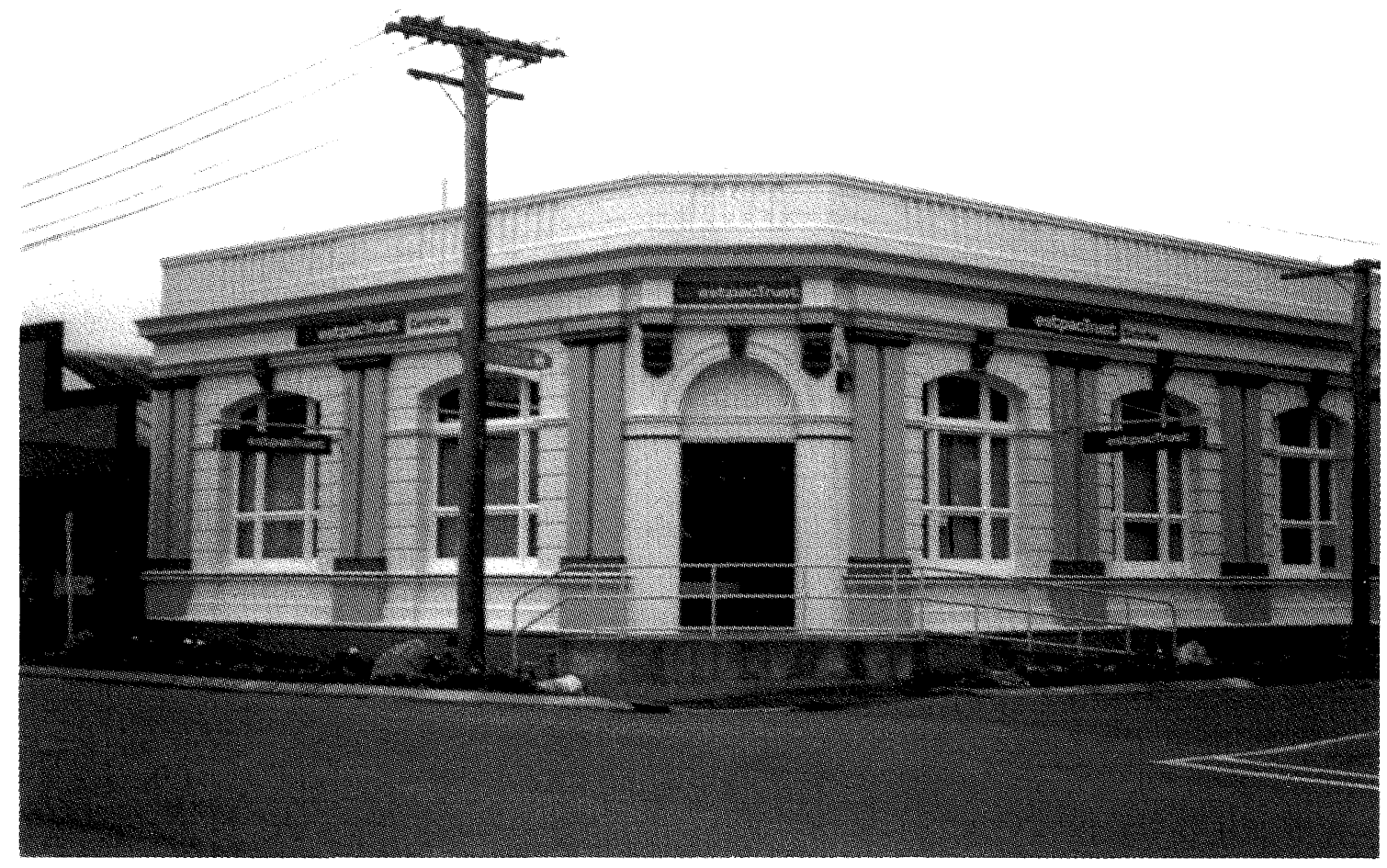

Figure 3(a): A pure brick single storey building, in 1942. The Bank of New South Wales in Carterton, which was moderately damaged $\left(D_{r}=0.06\right)$.

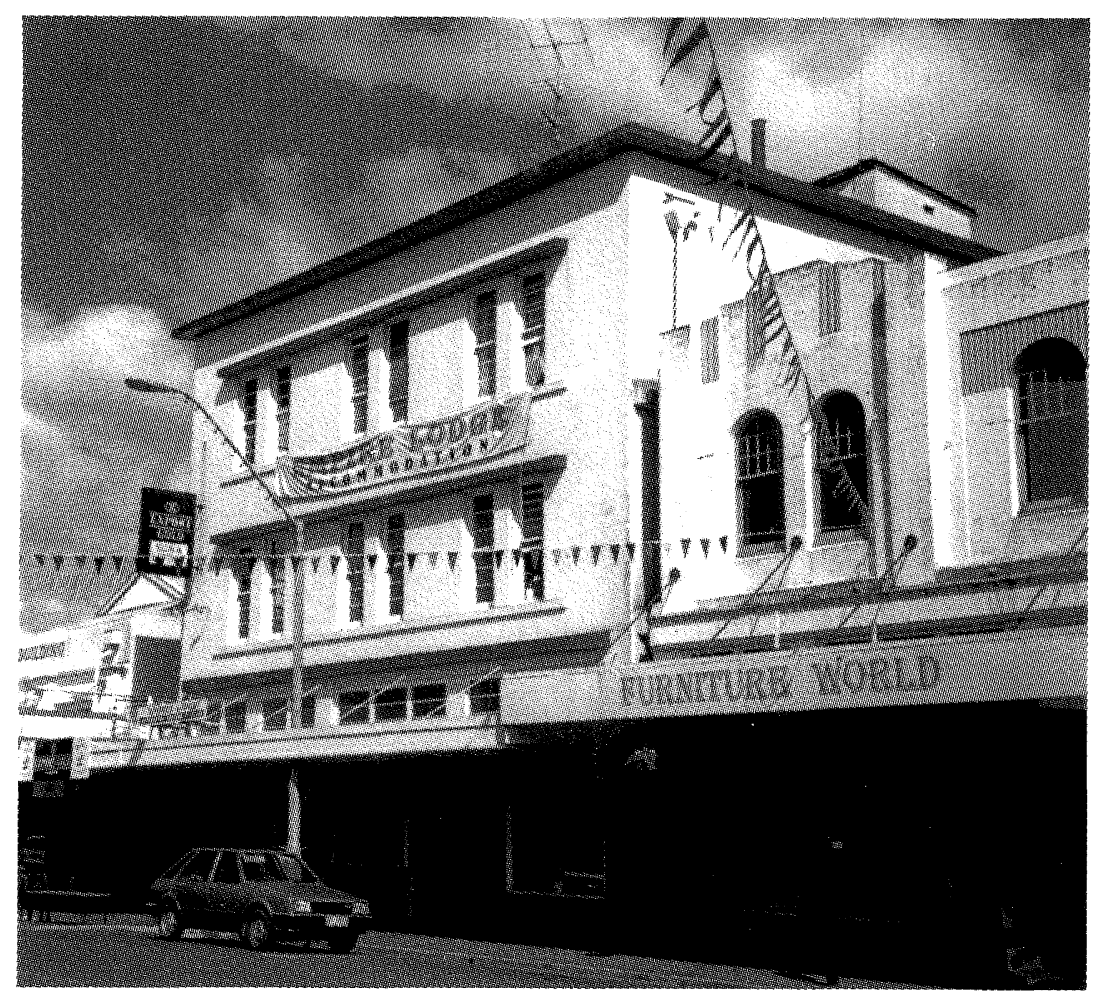

Figure 3(b): A pure brick three-storey building, in 1942. The Empire Hotel in Masterton, which was moderately damaged $\left(D_{r}=0.06\right)$. 


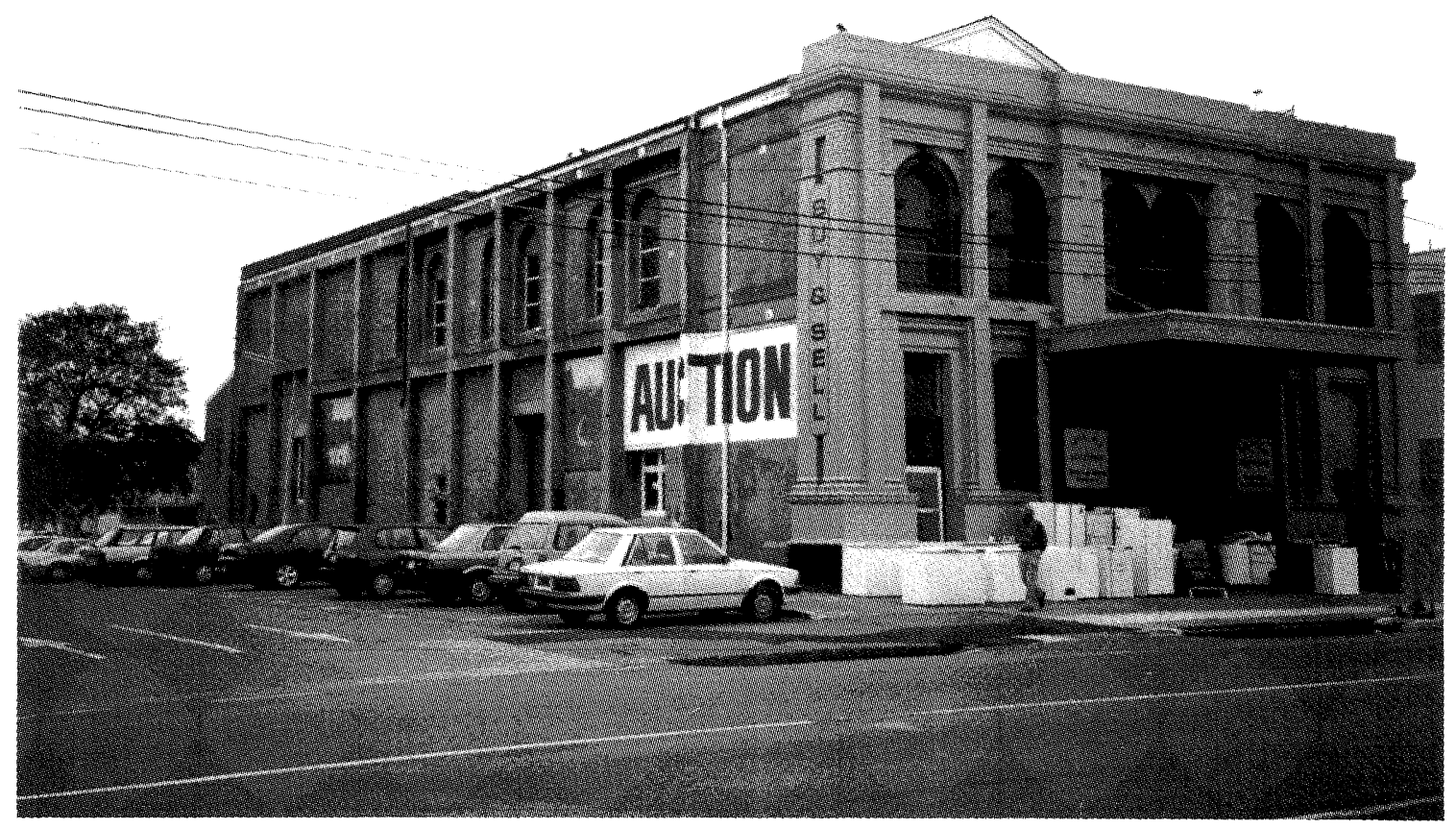

Figure 4: $\quad$ The Masterton Opera House in 1942, retrofitted partly after the 1934 Pahiatua earthquake and fully after 1942, as seen on the side wall. It was lightly damaged $\left(D_{r}=0.02\right)$.

Table 1:

Statistics of material damage costs and replacement values by class of non domestic brick building in the intensity MM8 zone of the Wairarapa earthquake of 24 June 1942.

\begin{tabular}{lcccc}
\hline Building Class & $\begin{array}{c}\text { Number of } \\
\text { Buildings N }\end{array}$ & \multicolumn{2}{c}{ Damage Cost $(\mathfrak{f})$} & $\begin{array}{c}\text { Replacement Value } \\
(\mathfrak{f})\end{array}$ \\
\hline Pure Brick & & Insured & Uninsured & $1,044,400$ \\
Hybrid & 111 & 44,170 & 76,396 & 146,200 \\
Part Retrofit & 10 & 2,043 & 2,400 & 109,700 \\
Total & 8 & 6,226 & 320 & $1,300,300$ \\
\hline
\end{tabular}

\subsection{THE DATA}

As in our previous studies [4 - 9], we attempted to account for all buildings of the class under consideration in order to avoid the problem of biased samples. In the present case we have accounted for nearly all such buildings in the MM8 intensity zone, excluding only a few for which the data was considered to be of inadequate quality. We consider that the data used is representative of the total population.

As mentioned earlier, local authority officials developed lists of most brick or part brick buildings for the six boroughs in the Wairarapa district. They included most private sector buildings and some owned by public utilities and local government, plus two of the Post Offices. The lists, while not complete in all details, included data on market value, insurance cover, insurance claims paid out, size of building, construction costs and costs of repairs to bylaw standards (which did not require compliance with the national earthquake standard). Costs of repairs were also obtained for a minority of the buildings from the files of the architect FC Daniell and the property owners known as Trust Lands Trust (who had earthquake insurance). The insurance sums paid out (for 32 buildings) were very similar to the amounts estimated by the borough officials.
It is important to note that the damage costs were for repair only, and contained no element of betterment or retrofitting. The data tabulated by the borough officers included a further estimate of costs for repairs and strengthening to conform to the national earthquake standard.

Much useful qualitative information held by the Wairarapa Archive in Masterton was also studied for verifying and amplifying the data used, including many photographs (especially from members of the Daniell family), design drawings, minutes of meetings and reports of the Reconstruction Committee, as well as the invaluable report by Harris \& Burns [12]

The replacement values of the buildings were based on their floor areas. Plan dimensions were given for almost all of the buildings in the tables of data prepared by the borough officials. These values were checked where possible, i.e. for most (66) of the Masterton buildings, and corrected where necessary. It was possible to do this easily because block plans, dated 1939 and 1967, existed for the central business area of Masterton. These plans were prepared by the Council of Fire \& Underwriters Association of New Zealand for fire rating purposes, and were drawn at a scale of 40 feet to the inch $(1: 480)$. An example of one town block is shown here in Figure 5. 


\section{QUEEN STREET}

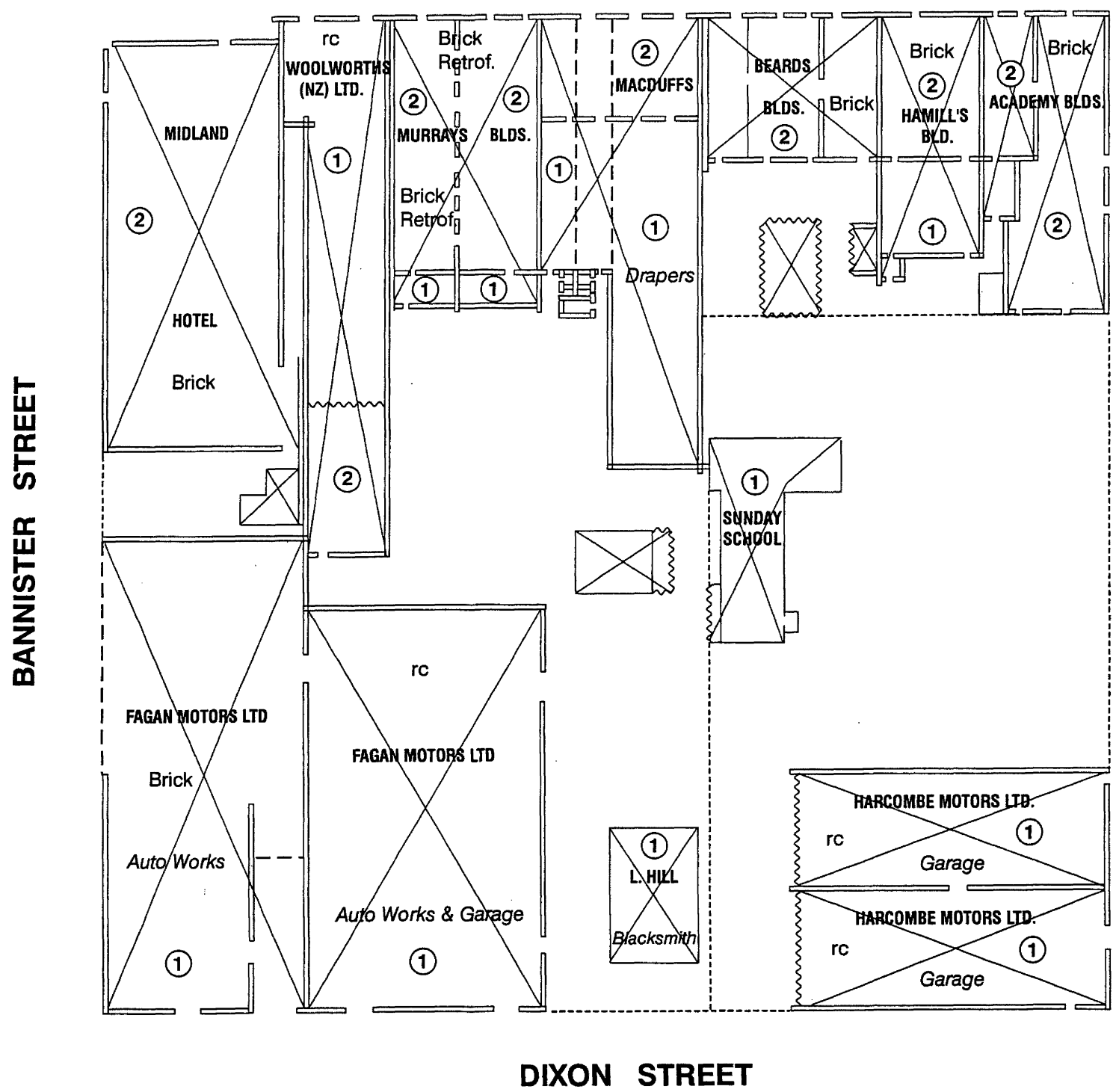

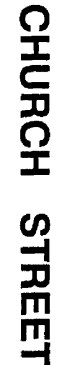

LEGEND
$\begin{array}{ll}\text { (2) } & 2 \text { storeys } \\ & \text { weatherboard } \\ & \text { brick or concrete } \\ \text { man } & \text { corrugated iron } \\ \text { rC } & \text { reinforced concrete }\end{array}$

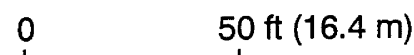

Figure 5: $\quad$ Plan of a town block in Masterton, dated 1939, prepared by the Council of Fire \& Accident Underwriters Associations of New Zealand showing building layouts. Brick and concrete construction added by Dowrick. 
The unit costs of constructing a new building in 1942 were based on the typical costs of run-of-the-mill commercial buildings, industrial buildings and warehouses, which were $\$ 1150, \$ 750$ and $\$ 500$ per square metre respectively in 1998 . As the Consumer Price Index was 43.5 in mid-1942 and 1101 in mid-1998, the unit building costs at the time of the earthquake are estimated as $£ 2.1, £ 1.4$ and $£ 0.9$ per square foot for the commercial, industrial and warehouse buildings respectively. Of the 129 buildings in our dataset, 109 were classed as commercial, 18 were industrial and two were warehouses. The resulting replacement values generally relate well to the market values and sums insured on a building-by-building basis, taking account of the building's age and condition where known. While the above method of estimating the replacement values may cause some moderate errors in the damage ratios estimated for individual buildings, the mean damage ratios of the larger subsets will be largely unaffected by it. Using the above repair costs based on actual costs or estimates based on current market rates, and the replacement values based on the Consumer Price Index (CPI), the estimates of damage ratio may be up to a factor of about 1.12 higher than they would have been in peace time market conditions. This occurs because repair costs were inflated by World War II conditions more than was the CPI. For example, the CPI increased by $16 \%$ from 1939 to 1943 , while in the dame period building costs had increased by about $30 \%$.

Because uncertainties in the global estimates of mean damage ratios are likely to be $5-10 \%$, we have not carried out any adjustments to allow for the above discrepancy, preferring to leave it in as a modest pessimistic effect on the estimated mean damage ratios.

Another feature of the repair costs that should be noted is that while they are nominally attributed to the intensity MM8 shaking that occurred in the largest event $\left(24^{\text {th }}\right.$ June) of the 1942 earthquake sequence, further damage was caused by the aftershocks, the costs of which are inseparably included in the repair costs used here. While most of the aftershocks were small and caused trivial extra damage, the $\mathrm{M}_{\mathrm{W}} 7.0$ earthquake of $1^{\text {st }}$ August (arguably not an aftershock), caused a maximum intensity of MM7 over a large area [1]. For the brick buildings considered here, it caused a moderate amount of extra damage in some cases. This phenomenon of aftershock contributions to damage costs within given $D_{r}$ values occurs in other datasets to various degrees, depending on whether repairs have been effected (and insurance claims settled where applicable) before any damaging aftershocks occur. Thus, this phenomenon not only contributes to interevent variability of damage ratios, but occurs in a manner that is generally not measurable.

Finally, it is noted that while seven of the pure brick buildings were written off (i.e. $D_{r}=1$ ), none collapsed (i.e. had volume losses $>50 \%$ ). This is consistent with the New Zealand version of the MM intensity scale for Buildings Type II (See Appendix 1). While no strong motion records were made at that time, it is of interest that the latest attenuation model [13] for New Zealand gives estimates of median $5 \%$ damped spectral acceleration $S_{A}(T=0.2 \mathrm{~s})$ in the range $0.5-1.0 \mathrm{~g}$ over the six towns involved, assuming source to site distances in the range $7-30 \mathrm{~km}$.

\subsection{DAMAGE COSTS}

The total costs of damage to the buildings in our dataset are given in Table 1, broken down into the amounts for each of the three vulnerability classes (i.e. brick, hybrid and partial retrofits) defined above. About 90 percent of the total population of brick buildings in the intensity MM8 zone are included.

Thirty-two of the buildings (i.e. 25\%) had earthquake insurance. Four of the eight partly retrofitted buildings and three of the 10 hybrid buildings were insured, leaving 25 (23\%) of the pure brick buildings insured. Thus, while $75 \%$ of the buildings were uninsured, as seen in Table 1 a smaller portion (i.e. 60\%) of the damage costs were uninsured. Judging from the reports on damage [12], the levels of insured damage cost and the estimated repair costs appear to be consistent with each other.

\subsection{DAMAGE RATIOS}

\subsection{Statistical Distributions of Damage Ratios}

The damage ratio $\left(D_{r}\right)$ for each building was calculated as defined by equation (1) above. All of the authors' other studies [e.g. 4-9] of earthquake damage have shown the shape of the statistical distribution of non-zero damage ratios for various classes of property to be well approximated by a truncated lognormal distribution. The lognormal distribution has the density function:

$f(x)=\frac{1}{\sigma x \sqrt{2 \pi}} \exp \left[-\frac{1}{2}\left(\log _{e} x-\mu\right)^{2} / \sigma^{2}\right] \quad x>0$

In the truncated form of the distribution as fitted to damage ratios, there is a "spike" at 1 , i.e., $P\left(D_{r}=1\right)=\int_{1}^{\infty} f(x) d x$. Here the parameters $\mu$ and $\sigma$ are estimated by the sample mean and standard deviation of the natural logarithm of the damage ratio of damaged items, with adjustments to compensate for properties having a damage ratio of $1[14]$.

The estimates of the parameters $\mu$ and $\sigma$ found for the various datasets are given in Table 2 . Also tabulated are the number of damaged items $n$, and the total population (damaged + undamaged) $N$.

\subsection{Mean Damage Ratios}

The mean damage ratio for all buildings in a given MM intensity zone is a useful parameter for various purposes [7], e.g. in comparing the earthquake resistance of different classes of property. Considering all $N$ buildings (damaged and undamaged) in an MM intensity zone, we give here two principal ways of defining the Mean $D_{r}$. Firstly,

$\bar{D}_{r}=\frac{\sum_{i=1}^{n} \text { [cost of damage to building } i \text { ] }}{\sum_{i=1}^{N} \text { [value of building } i \text { ] }}$ 
Secondly

$D_{r m}=\frac{\sum_{i=1}^{n}\left[D_{r_{i}}\right]}{N}$

If derived from large, homogeneous populations, $\bar{D}_{r}$ and $D_{r m}$ tend to be similar in value, while for more inhomogeneous populations (with large ranges of replacement values and vulnerabilities) $\bar{D}_{r}$ and $D_{r m}$ may differ widely. The values of $\bar{D}_{r}$ and $D_{r m}$ for the three classes of non-domestic building considered in this study are presented in Table 2. As $D_{r m}$ and its associated confidence limits are generally more reliable and useful than $\bar{D}_{r}$ [7], the former are used throughout this paper.

Next we compare the vulnerability of different classes of property in terms of their statistical distributions, mean damage ratios, proportions of population damage, and uncertainties.

Table 2: $\quad$ Basic statistics of the distribution of damage ratios by class of non-domestic brick building in the intensity MM8 zone of the Wairarapa earthquake of 24 June 1942.

\begin{tabular}{lcccccc}
\hline \multicolumn{1}{c}{ Building Class } & $n$ & $N$ & $\mu$ & $\sigma$ & $D_{r m}$ & $\bar{D} r$ \\
\hline Pure Brick & & & & & & \\
& & & & & & \\
All & 107 & 111 & -2.18 & 1.36 & 0.17 & 0.12 \\
1 Storey & 65 & 69 & -2.32 & 1.13 & 0.14 & 0.11 \\
2+ Storey & 42 & 42 & -1.95 & 1.70 & 0.22 & 0.12 \\
& & & & & & \\
Hybrid and Part Retrofit & & & & & & \\
& 13 & 18 & -3.14 & 1.38 & 0.041 & \\
All & 7 & 10 & -3.05 & 0.67 & 0.036 & 0.030 \\
All Hybrids & 6 & 8 & -3.25 & 2.02 & 0.047 & 0.060 \\
All Part Retrofits & & & & & & \\
\hline
\end{tabular}

\subsection{Effects of Construction Materials}

Plots of cumulative probability of damage ratios at intensity MM8 in the Wairarapa earthquake are shown in Figure 6(a) for two classes of building, i.e. pure brick, and hybrid plus partial retrofits (defined in Section 2.0). The shapes of the plots are broadly similar to the fitted lognormal curves, but the fits are not as close as we have obtained in studies of larger datasets $[5,6,9]$. A close fit is not to be expected in the case of the hybrids and retrofits subset, as this comprises only 18 buildings. In the case of the pure brick buildings, the poor fit seems to be due to combining one and two-storey buildings in a single distribution. These two subsets have rather different distributions, and in particular the damage ratios of the two-storey buildings have a wider dispersion ( $\sigma=1.70$ compared to $\sigma=1.13$ for one-storey buildings, Table 2). A much closer fit was obtained for the single storey pure brick buildings alone.

When considering mean damage ratios and percentages of buildings damaged, all three building classes are plotted (Figures 6(b) and (c)). It is seen from these plots that the hybrid and partly retrofitted buildings behaved very similarly with almost identical values of $D_{r m}$ and $n / N$. In addition, the beneficial effect of even small amounts of reinforcing steel is very apparent in all three plots of Figure 6 . In particular, $D_{r m}$ for the reinforced buildings at about 0.04 is only a quarter of the value for pure brick $(0.17)$. The proportion of pure brick buildings damaged is $96 \%$ compared with $72 \%$ for the hybrids and partial retrofits.

\section{$5.4 \quad$ Number of Storeys}

The vulnerabilities of pure brick buildings of one and two storeys at intensity MM8 are compared in Figure 7, where their $D_{r m}$ and the associated $95 \%$ confidence limits are plotted. The vulnerability of two-storey buildings $\left(D_{r m}=\right.$ 0.22 ) is substantially greater than that for one-storey buildings $\left(D_{r m}=0.14\right)$. The numbers of buildings in each class is not large and the confidence limits are quite wide. The difference in the above two values of $D_{r m}$ was found not to be statistically significant, but only just, the $p$-value of the difference being 0.057 .

The above findings are similar to those for one and two storey non-domestic buildings at MM7 and MM9 in the Edgecumbe earthquake [6], and for houses at MM7 and MM8 in the 1968 Inangahua earthquake [9].

\subsection{Damage Ratios as a Function of Building Size}

The possibility that damage levels might vary with building size was examined. In Figure 8 the damage ratio for each pure brick building is plotted against its floor area (in square feet), and a robust smooth trend line is fitted for both onestorey and two-storey buildings. The trend line was fitted using a locally weighted regression smoothing function (lowess) as implemented in the statistical package S-plus [15]. This trend line is locally linear at any point and is calculated by a weighted least squares algorithm which gives a low weight to outliers. 


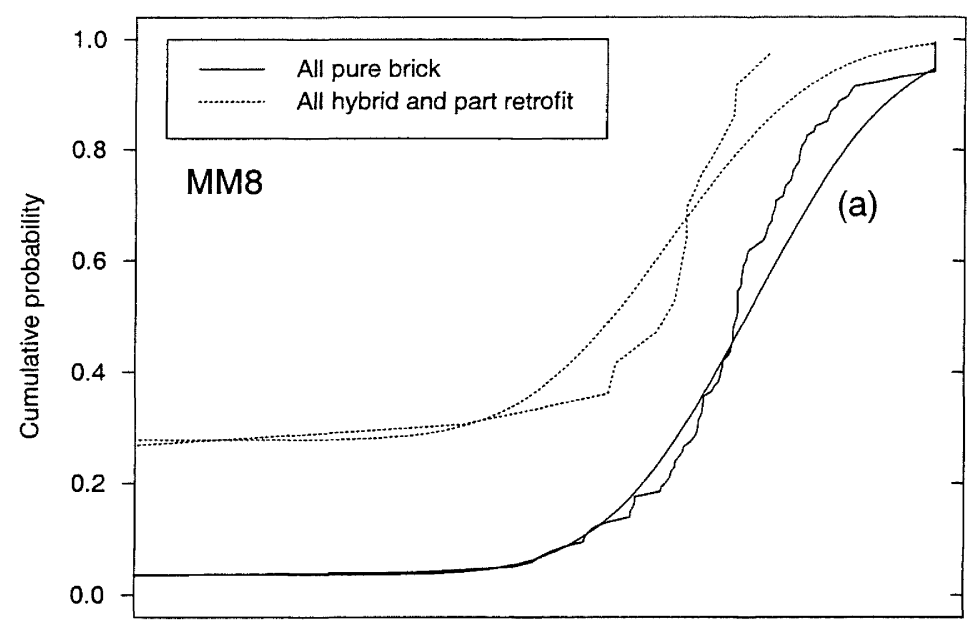

Damage ratio
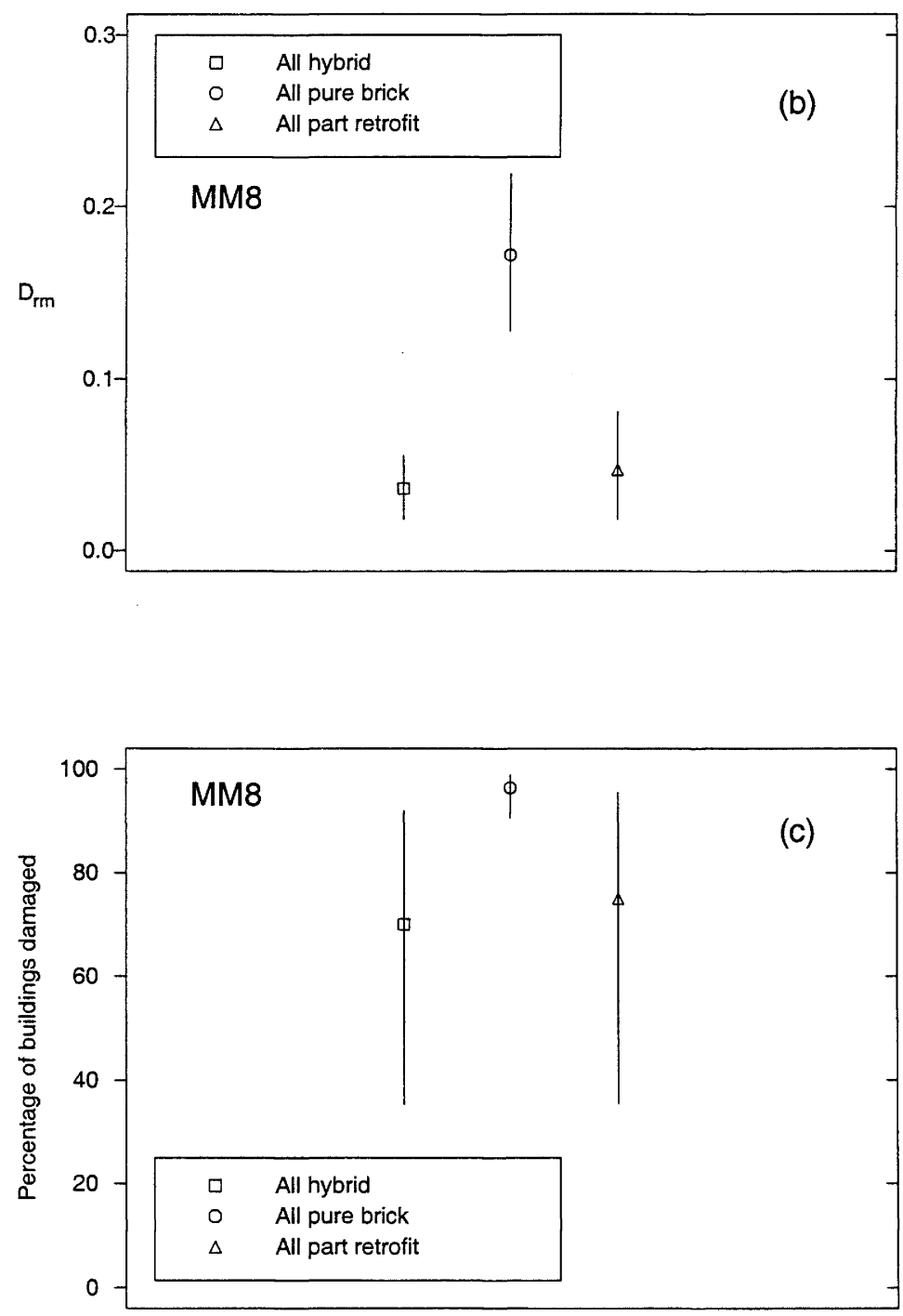

Figure 6: Three measures of vulnerability for three classes of non-domestic brick buildings in the MM8 intensity zone of the June 1942 Wairarapa earthquake: (a) Cumulative probability distributions of damage ratio, (b) $D_{r m}$ and its 95\% confidence limits, and (c) Percentage of buildings damaged with its $95 \%$ confidence limits. 


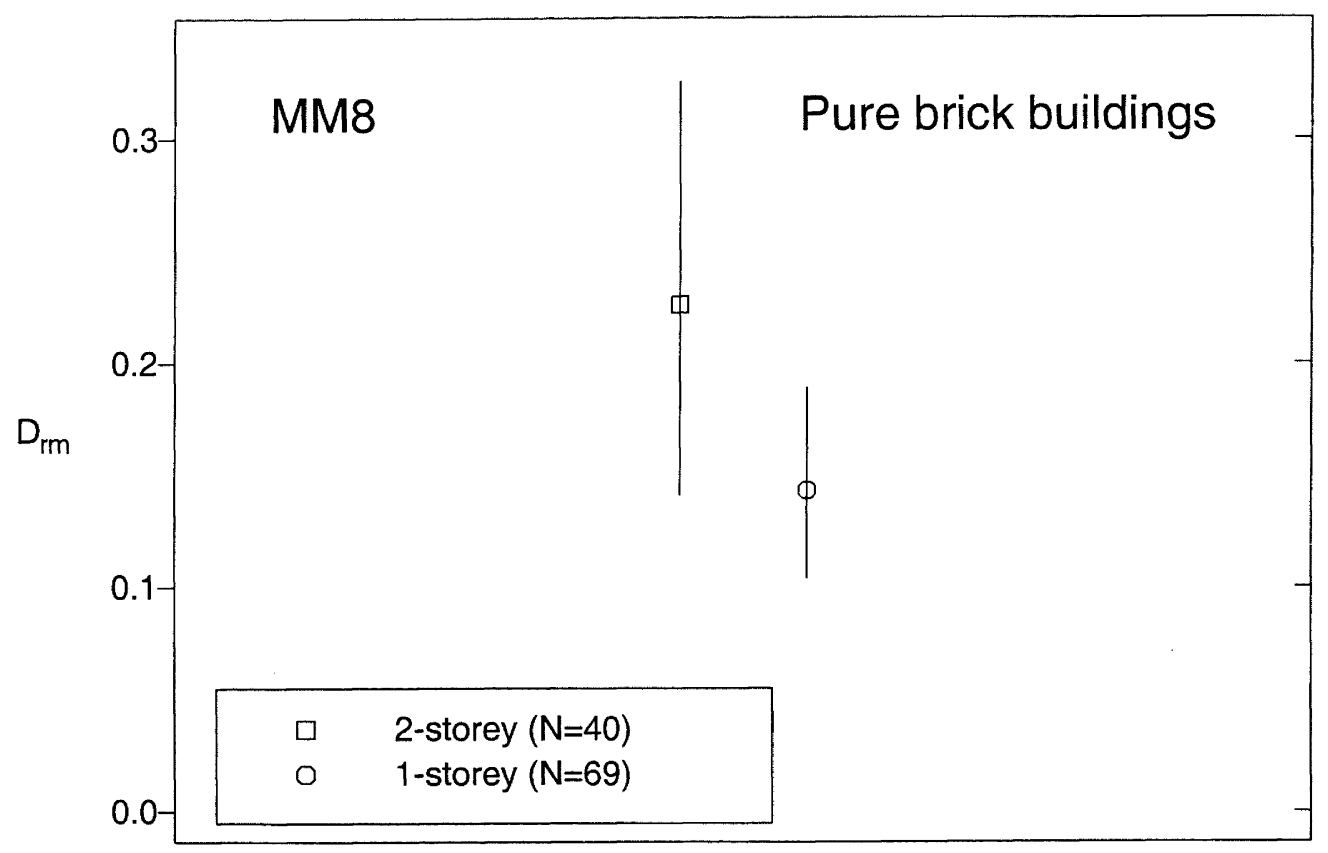

Figure 7: $\quad D_{r m}$ and its $95 \%$ confidence limits for one and two-storey non-domestic pure brick buildings in the MM8 intensity zone of the June 1942 Wairarapa earthquake.

Figure 8 shows clear trends for the smoothed damage ratio to decrease with increasing building size, for both one and twostorey buildings. This contrasts to the lack of correlation between $D_{r}$ and replacement value found for 1935-1986 nondomestic buildings at intensity MM9 in the Edgecumbe earthquake [6], and also found for timber framed houses excluding chimney damage at MM8 in the Inangahua earthquake [9]. The trends shown in Figure 8 explain why for pure brick buildings $\bar{D}_{r}$ with a value of 0.17 is $50 \%$ greater than $D_{r m}$ (Table 2), $\bar{D}_{r}$ being heavily influenced by the lower damage levels of the larger buildings. A larger dataset might not have this trend. The trend could be due to the effect of some unidentified physical variable that influences the damage ratio and happens, for this data set, to be correlated with floor area.

\subsection{Site Conditions}

The buildings considered in this study were located in six different towns, five of which are flat firm to stiff alluvial areas, while Eketahuna (where the damage levels were highest) is on undulating mudstone. The alluvium varies in type and thickness (>100 m), but is mostly of a firm to stiff character, which would be classed as Ground Class C, as defined in the loadings standard NZS4203.1992.

The number of buildings (129) in our database was considered to be insufficient to differentiate microzone effects on damage levels.

\subsection{COMPARISONS WITH OTHER STUDIES}

As mentioned earlier, the pure brick buildings studied here represent the second most vulnerable class of New Zealand buildings, and this is the first time that the vulnerability of such buildings has been evaluated in damage ratio terms. It is therefore of particular interest to compare the vulnerabilities evaluated here with those obtained for other classes of New Zealand buildings. This is done in terms of mean damage ratio and percentage of buildings damaged, in Figures 9(a) and 9 (b) respectively. All the results plotted are for one storey buildings, because they comprise the largest subsets of data and hence have the most robust results. The results plotted from other studies are:

- Non - domestic concrete masonry (1935-1979), Edgecumbe earthquake, intensities MM7 and MM9 [6].

- Timber framed houses with brittle chimneys, Inangahua earthquake, intensities MM7 - MM9 [9].

- Timber framed houses excluding chimney related damage, Inangahua earthquake intensities MM7 - MM9 [9].

As seen in Figure 9(a), $D_{r m}$ for pure brick one storey buildings at MM8 is 2.9 times higher (at 0.14 ) than the next worst class of buildings, i.e. houses with brittle chimneys, for which $D_{r m}=0.048$ at MM8 and 0.050 at MM9. In addition, the $95 \%$ confidence limits are widely separated. Also shown in Figure 9(a), $D_{r m}$ for pure brick is approximately seven times greater than that $(\sim 0.02)$ for 1935 - 1979 code-designed concrete masonry buildings (estimated by linear interpolation between the Edgecumbe earthquake MM7 and MM9 $D_{r m}$ values).

From Figure 9(a) it is also of interest to compare the vulnerability of the brick buildings with our most robust class of buildings, i.e. timber houses without chimney damage. The ratio of the $D_{r m}$ values for these two classes of buildings is $0.14 / 0.005=28$. This ratio is comparable to (but greater than) the ratio of the most and least vulnerable classes of equipment (and plant), i.e., "fragile" and "robust", found from the Edgecumbe earthquake [16]. For equipment, this ratio was found to be 23 and 14 at intensities MM7 and MM9 respectively. 


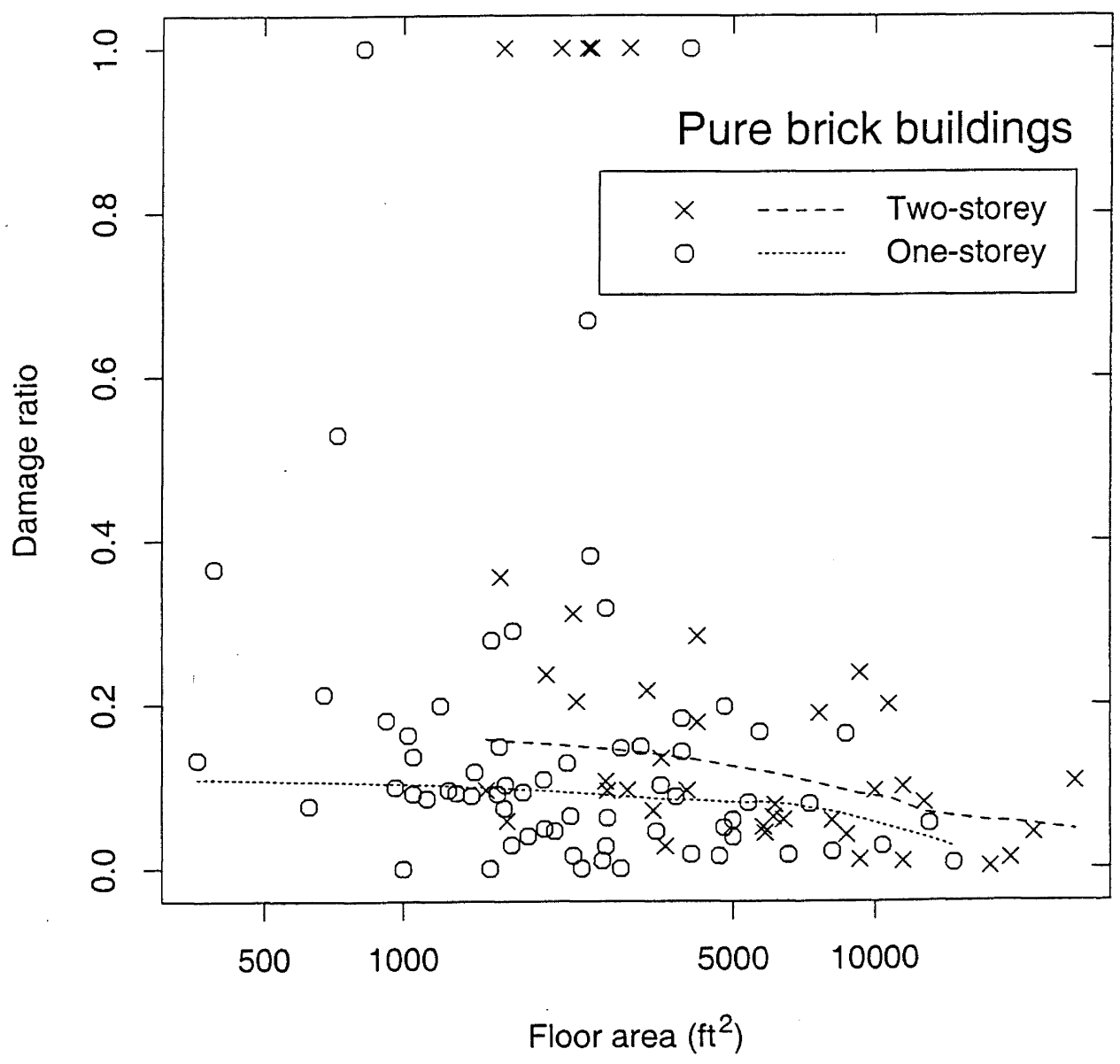

Figure 8: $\quad$ Plot of damage ratio versus floor area for one and two-storey pure brick buildings in the MM8 intensity zone of the June 1942 Wairarapa earthquake, including a robust fit of the median damage ratio curve.

Considering the percentage of buildings damaged (Figure 9(b), pure brick buildings are again worse $(92 \%)$ than the next worst class of buildings, houses with brittle chimneys, for which $n / N=81 \%$ at both MM8 and MM9. Reinforced concrete masonry buildings from the Edgecumbe earthquake have $n / N=35 \%$, estimated by linear interpolation between the MM7 and MM9 results.

We know of no other published estimates of damage ratios for brick buildings based on actual costs and replacement values, the nearest being those derived from buildings in part of San Francisco (MM7?) of the Loma Prieta earthquake [17], but actual repair costs were not used and the appropriate intensity is uncertain. Of course there have been many instances worldwide of total destruction of URM which imply a mean damage ratio of 1.0 .

\subsection{CONCLUSIONS}

Arising from this study the following conclusions have been made:

1. The damage ratios estimated here account for repair costs only, and hence do not include the costs of the strengthening or betterment which would be required today.
2. The vulnerability of non-domestic low-rise brick buildings has been determined in terms of probability distributions of damage ratio, mean damage ratio and percentage of buildings damaged at intensity MM8. Modeled median ground motions for the sites involved were in the range $0.5 \leq S_{A}(T=0.2 \mathrm{~s}) \leq 1.0 \mathrm{~g}$ for elastic response and $5 \%$ of critical damping.

3. Brick buildings with quite primitive reinforcement (hybrids and partial retrofits) are much less vulnerable at intensity MM8 than pure brick buildings. The mean damage ratio, $D_{r m}$, for all the reinforced brick buildings was $24 \%$ of that for all the pure brick buildings, and the incidence of damage was also substantially reduced.

4. Brick buildings built originally with some reinforcement (hybrids) were equal in vulnerability to partially retrofitted buildings. But as the populations of these two classes of buildings were small, this finding should be interpreted qualitatively rather than quantitatively.

5. The mean damage ratio for two-storey pure brick buildings at 0.22 was $57 \%$ greater than that for onestorey buildings. The difference between the $D_{r m}$ values for these two subsets fell just short of statistical significance $(p=0.057)$, but is consistent with the differences between one and two-storey buildings found in studies of the Edgecumbe and Inangahua earthquakes. 

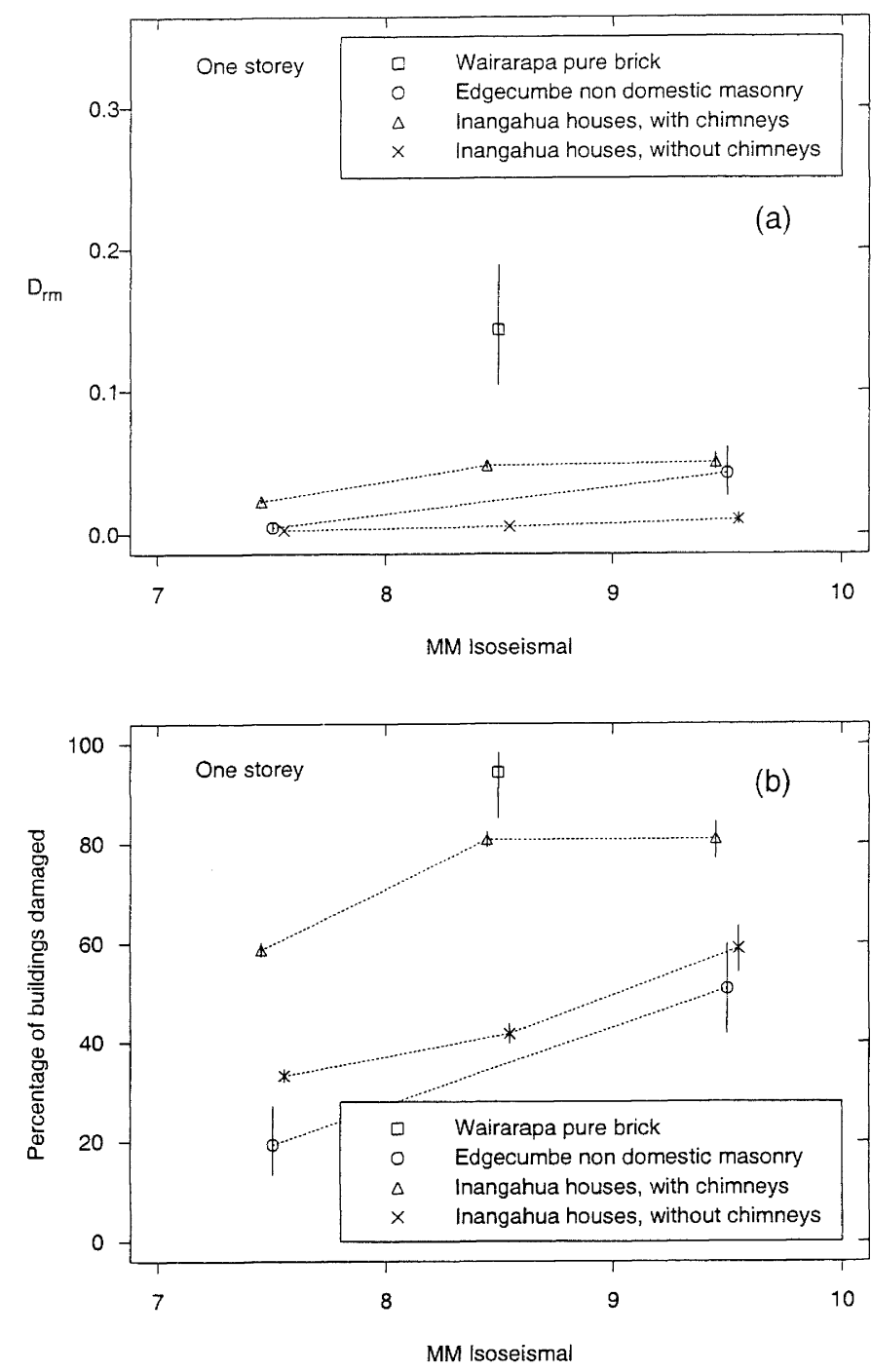

Figure 9: $\quad$ Two vulnerability measures for pure brick Wairarapa non-domestic buildings compared with those for three other building classes from the 1968 Inangahua and 1987 Edgecumbe earthquakes: $\quad$ (a) $D_{r m}$ with its $95 \%$ confidence limits, and (b) Percentage of buildings damaged with its $95 \%$ confidence limits. The houses are timber framed.

6. The mean damage ratio for both one and two-storey pure brick buildings was found to reduce substantially with increasing floor area. Such a trend has not been seen before, except in houses with chimney damage, and the reason for it is not evident. This trend explains why $\bar{D}_{r}$ is so much smaller than $D_{r m}$ for these two subsets.

7. While the vulnerabilities were not evaluated in terms of microzones, it should be noted that $87 \%$ of the buildings studied were situated on flat, deep, firm to stiff alluvium (Ground Class C in NZ4203: 1992) and the remainder were on gently undulating weak mudstone (Ground Class A).

8. Comparing one-storey buildings at intensity MM8, the mean damage ratio for the pure brick Wairarapa buildings is (1) approximately three times that for timber framed houses with brittle chimneys in the 1968 Inangahua earthquake; (2) seven times that for 1935 1979 concrete masonry buildings in the Edgecumbe earthquake; and (3) 28 times that for timber framed houses excluding chimney damage in the Inangahua earthquake.
9. Measured in terms of $D_{r m}$ at intensity MM8, the relative vulnerability of brick buildings compared to the most robust class of houses (so far evaluated) is similar to that for the most and least vulnerable classes of equipment and plant in the 1987 Edgecumbe earthquake.

\section{ACKNOWLEDGEMENTS}

This study was funded by FRST under Contract No's. C05804 and C05X0006. Much of the data used in this study was derived from material held by the Wairarapa Archive in Masterton and we are greatly indebted to the indefatigable assistance and great personal knowledge of the Wairarapa archivist, G. Winter. Thanks are due to $\mathrm{J}$ Cousins and $\mathrm{N}$ Perrin for their in-house reviews of the manuscript and also to an unknown reviewer.

In addition, various people in the affected area helped by providing information on the buildings studied. In particular our thanks go to the following: 
Carterton:

Featherston

Greytown:

Martinborough:
J McKenzie, B Tunnicliffe

Mrs P Flynn

J Garrity, D Milne

P Jenkins, O Thomas

\section{REFERENCES}

1. Downes G.L., Dowrick D.J., van Dissen R.J., Taber J.J., Hancox G.T. and Smith E.G.C. (2001), "The 1942 Wairarapa, New Zealand, earthquakes: analysis of observational and instrumental data". Bulletin NZ Society of Earthquake Engineering, 34(2), 125-127.

2. Dowrick D.J. and Rhoades D.A. (1998), "Magnitudes of New Zealand earthquakes, 1901 - 1993”, Bulletin NZ National Society for Earthquake Engineering, 31(4), $260-280$.

3. Doser D.I. and Webb T.H., "Source parameters of large historic (1917-1961) earthquakes, North Island, New Zealand", (in prep)

4. Dowrick D.J. (1991), "Damage costs for houses and farms as a function of intensity in the 1987 Edgecumbe earthquake". Earthquake Engineering and Structural Dynamics, 20: 455-469.

5. Dowrick D.J., Rhoades D.A., Babor J. and Beetham R.D. (1995), "Damage ratios and microzoning effects for houses in Napier at the centre of the magnitude 7.8 Hawke's Bay, New Zealand, earthquake of 1931". Bulletin New Zealand National Society for Earthquake Engineering, 28(2): 134-145.

6. Dowrick D.J. and Rhoades D.A. (1997), "Vulnerability of different classes of low-rise buildings in the 1987 Edgecumbe, New Zealand, earthquake". Bulletin New Zealand National Society for Earthquake Engineering, 30(3): 227-241.

7. Dowrick D.J. and Rhoades D.A. (1997), "Inferences for design, insurance and planning from damage evaluation in past New Zealand earthquakes". Journal of Earthquake Engineering, 1(1): 77-91.

8. Rhoades D.A. and Dowrick D.J. (1999), "Variability of damage ratios for property in earthquakes". Earthquake Spectra, 15(2): 297-316.

9. Dowrick D.J., Rhoades D.A. and Davenport P.N (2001), "Damage ratios for domestic property in the magnitude 7.2 1968 Inangahua, New Zealand, earthquake". Bulletin NZ Society for Earthquake Engineering, 34(3): 191-213.

10. Dowrick D.J. (1996), "The Modified Mercalli earthquake intensity scale - Revisions arising from recent studies of New Zealand earthquakes". Bulletin New Zealand Society for Earthquake Engineering, 29(2): 92-106.

11. Downes G., Dowrick D.J., Smith E. and Berryman K. (1999), "The 1934 Pahiatua earthquake sequence: Analysis of observational and instrumental data". Bulletin NZ Society for Earthquake Engineering, 32(4): 221-245.

12. Harris A.G. and Burns D.J. (1942), "Earthquake Damage". Unpublished Reports by Borough Surveyors, prepared for C.R. Mabson, Borough Engineer, on nondomestic buildings in the Borough of Masterton, $2^{\text {nd }}$ July and $17^{\text {th }}$ July, plus addenda dated $22^{\text {nd }}$ August 1942.

13. McVerry G.H., Zhao J.X., Abrahamson N.A. and Somerville P.G. (2000), "Crustal and subduction zone attenuation relations for New Zealand". Proceedings $12^{\text {th }}$ World Conference on Earthquake Engineering, Auckland, Paper No. 1834.

14. Dowrick D.J. and Rhoades D.A. (1993), "Damage costs for commercial and industrial property as a function of intensity in the 1987 Edgecumbe earthquake". Earthquake Engineering and Structural Dynamics, 22: 869-884.

15. MathSoft (1998), S-Plus 5 for Unix Guide to Statistics. Data Analysis Products Division, MathSoft, Seattle, $1014 \mathrm{pp}$.

16. Dowrick D.J. and Rhoades D.A. (1995), "Damage ratios for plant, equipment and stock in the 1987 Edgecumbe, New Zealand earthquake". Bulletin NZ National Society for Earthquake Engineering, 28(4): 265-278.

17. Rutherford \& Chekene (Lizundia, et al.) (1991), "Damage to unreinforced masonry buildings in the October 17, 1989 Loma Prieta earthquake". Report for the National Science Foundation and California Seismic Safety Commission. 
APPENDIX 1: $\quad$ Extract from the New Zealand 1996 Modified Mercalli scale [10]

\section{Criteria for MM8 relating to pre-code structures:}

Buildings Type I, heavily damaged, some collapse.

Buildings Type II damaged, some with partial collapse

Buildings Type III damaged in some cases.

Monuments and pre-1976 elevated tanks and factory stacks twisted or brought down

Some pre-1965 infill masonry panels damaged.

Decayed timber piles of houses damaged.

Houses not secured to foundations may move.

Most unreinforced domestic chimneys damaged, some below roofline, many brought down

\section{Construction Types:}

Buildings Type I

Buildings with low standard of workmanship, poor mortar, or constructed of weak materials like mud brick or rammed earth soft storey structures (e.g. shops) made of masonry weak reinforced concrete or composite materials (e.g. some walls timber, some brick) not well tied together. Masonry buildings otherwise conforming to buildings Types I - III, but also having heavy unreinforced masonry towers.

\section{Buildings Type II}

Buildings of ordinary workmanship, with mortar of average quality. No extreme weakness, such as inadequate bonding of the corners, but neither designed nor reinforced to resist lateral forces. Such buildings not having heavy unreinforced masonry towers.

\section{Buildings Type III}

Reinforced masonry or concrete buildings of good workmanship and with sound mortar, but not formally designed to resist earthquake forces. 